Role of agricultural engineering in environmental and sustainable development

for the valley and delta areas. 1630 - 1650

\title{
DESIGN AND EVALUATION OF MECHANICAL AID TOOLS FOR MANGO FRUITS HARVESTING
}

\author{
M.E. El-Iraqi ${ }^{1}$; Y. Sharibim ${ }^{2}$ and S.E. El Khawaga ${ }^{1}$
}

ABSTRACT

The main objective of the present study is to design and fabricate simple, low cost and portable mechanical harvesting aid of mango fruits for fresh marketing and exporting that assure having fair fruit quality with minimal twig height, and maximizing manual labor productivity in order to minimize the cost of manual picking. Therefore, four designed prototypes of mechanical harvesting aid tools namely mechanical disk cutter, electrical disk cutter, electrical scissors and cutting edge hook were designed and locally fabricated at some private workshops. The harvesting tools under study were evaluated and tested for harvesting Zebda and Hindi mango fruit varieties (mangifera indicia L.) using three different picking labors for each harvesting tool. The obtained results allow us to drawn the following conclusions:

- The labor productivity increased by about 430.8, 240.1, 229.4 and $50.7 \%$ for harvesting Zebda mango fruits and about 401.9, 215.2, 190.1 and 55.5\% during harvesting Hindi mango fruits by using the mechanical disk cutter, electrical scissors, electrical disk cutter and cutting edge hook instead of using traditional stalk hook, respectively.

- The lowest injured fruit percentage (3-4 and 3-4\%) were obtained by using electrical scissors followed by electrical disk cutter (3-4 and 45\%), then mechanical disk cutter (5-6 and 4-5\%) for harvesting Zebda and Hindi mango fruits varieties, respectively. However, the highest values of validity period were 6-7 days and 8-9 days for harvesting Zebda and Hindi mango fruits varieties, respectively by using any of mechanical disk cutter, electrical scissors and electrical disk cutter.

\footnotetext{
${ }^{1}$ Senior Researcher, Agric. Eng. Res. Inst., Agric. Res. Center.

${ }^{2}$ Head of Research, and Chief of Machinery Design Dept., Agric. Eng. Res. Inst., Agric. Res. Center.
} 


\section{INTRODUCTION}

7 he quality of the harvested crop is very important for fresh fruit production as the quality of fresh fruit will secure both the price and sale volume. The quality of fresh fruit depends on not only from intensive care, handling operation before harvesting and the proper mature stage of harvesting but also the method of harvesting and handling operation employed in the process. Fruit harvesting for fresh fruit market is mostly accomplished by hand picking, harvesting tools or manpositioning platforms (Ryall and Pentzer, 1982). Fresh market perishable fruit offer the biggest challenge for mechanization. Lack of uniform maturity and differences in criteria for readiness for harvest between different fruit crops, and even between species and varieties made it, so far, impossible to substitute machines for human judgment and dexterity (Peterson and Miller, 1988).

Pataweerat (1989) reviewed various fruits harvesting methods in Thailand with the emphasis on availability of picking methods and tools. Presently, there are various kind of harvesting methods such as for young trees where hand picking is convenient, farmers will use scissor to cut fruit with a length of peduncle attached and collect in basket. To obtain fruit that is beyond reach, they would use ladder or climbing up the tree and then harvest with ratten-takraw, or using trimming scissor are used to cut the fruit around the radius stem, When the ratten-takraw is full, the mangoes will be transferred to container hanging on the tree near the picker. When the collected container is full the hanging rope will be extended to allow the containers reaching the ground for further transfer to the new container. The picking by ratten-takraw causes draining of latex staining on the peel of mangoes while picking by trimming scissors gives mango with attached peduncle but this operation allows one fruit or one group per batch which is a very slow process.

Pataweerat et. al (1990) designed and tested two types of harvesting machine for mango. Type I consisted of 3 -wheel vehicle driven with small power engine, controlled direction at front wheel and needed two operators. They found that harvesting machine Type 1 of $175.0 \mathrm{~cm}$ wide and $373.5 \mathrm{~cm}$ long with un-adjustable vehicle operating floor could pick 
the mango at the level of 2.7 meter height form the ground. The operator should be at least $1.65 \mathrm{~m}$ tall. The rate of picking was 6.29 second per fruit when compared with ratten-takraw of $15.52 \mathrm{sec} /$ fruit. The problems of Type I harvesting machine were that the difficulty of power engine to drive on rough and big soil, wide angle of turn round, uneasy operation and limiting of high mango tree which far from hand picking, harvesting machine of type 2 consisted of $151 \mathrm{~cm}$ wide, $306 \mathrm{~cm}$ long, adjustable vehicle operation floor with hydraulic system of 79 to 140 $\mathrm{cm}$ high from the ground. The testing results showed that it could harvest 3.5 meter high from the ground with average time of 6.26 seconds per fruit while together with the ratten-takraw of 4.25 meter long, it could pick at the level of 7-8 meter high from the ground with picking rate of 15.07 second per fruit. Harvested mango without peduncle was $6 \%$ with hand picking and $60 \%$ with ratten-takraw.

Jarimopas and Pataweerat (1993) employed five means of mango harvesting, a) ratten-takraw, b) locally-made 4 wheel harvesting vehicle, c) 3-wheel harvesting vehicle, d) locally-made 4 wheel harvesting vehicle together with 2-m long ratten-takraw, and e) 3-wheel harvesting vehicle together with 2-m long ratten-takraw. To harvest mangoes of KeoSavoey variety, at three different heights ranges of the mango tree 24 meters, 4- 6 meters, and beyond 6 meters. The harvesting vehicle with ratten-takraw exhibited the highest harvesting rate of $141 \mathrm{~kg} / \mathrm{h}$, while the use of ratten-takraw could work averagely $76 \mathrm{Kg} / \mathrm{h}$.

Kitinoja and Kader (2002) reported that a variety of styles are available like hand hold or pole models, including shears that cut and hold onto the stem of cut product. This feature allows picker to harvest without a catching bag and without dropping fruits. A jackfruit harvester is fabricated with this principle. Harvester consists of a long telescopic pole with a hook knife at the top. Besides, a rope-woven basket attached to metallic frame tied to a long rope is used for holding detached fruit and lower its safely to ground.

Abu-Goukh and Mohamed (2004) studied the effect of harvesting method on quality and shelf-life of mango fruits. They indicated that instead of letting the fruits fall to the ground, mangoes were harvested by 
an improved technique. Whereas, fruits were snapped off the tree with a pole equipped with a long cloth sleeve held open by a ring. When the pedicel was severed, the fruit dropped into the bag and slid smoothly down to be received by the picker. The improved method greatly improved fruit quality, reduced post-harvest losses and extended the shelf-life.

Weor (2007) investigated the effects of various methods of harvesting Peter mango fruits on storability under different environments in Gboko, Benue State, Nigeria. The experiment consisted of five harvesting methods (pole and collection bag, hand pick, foam, grass method and the traditional method). The traditional which is pluck-and-drop method was carried out with a rod of $3 \mathrm{~m}$ long and a hook at the end. The pole and collection bag method consisted of a plucking technique using a rod of convenient length $(1-2 \mathrm{~m})$ equipped with a collecting bag near the hook. The pluck-and-drop method was modified such that the fruits dropped on foam (foam method) or grass (grass method). Five harvested fruits were selected from each harvesting method and stored in store, porch and thatched hut. The results showed that Peter mango fruits stored longer when harvested using improved methods of pole and collection bag, hand pick, foam and grass method than the traditional method (pluck and drop) that is normally used by most farmers. Farmers can adapt any of these three improved methods of harvesting, and store in cool environment, such as thatch hut.

\section{Problem statement}

Mango is an important tropical fruit having heavy demand in world market. and is rightly designated as the king of fruits. It is consumed both as fresh and processed forms. According to Mukherjee, (1996) the major producing countries are Egypt, Madagascar, Nigeria, Sudan, Tanzania and Democratic Republic of Congo. Egypt grows mangoes in more than 55,470ha in 2008 which produced 466,440 ton throughout most the country Governorates. The most important varieties are Hindi, Pairi, Tymour, Ewas, Zebda and Langara. The export quantity in 2008 about 2470 ton by about 1.54 million U.S. Dollars. Therefore, the 
Egyptian mango fruit has a big economic importance and take the $3^{\text {rd }}$ order in trade after grape and citrus fruits. (AOAD, 2009).

The main problem affecting on the loss income of mango producers in Egypt is harvesting mango fruits for fresh marketing especially in old mango farms, which the tree height reach to more than $12 \mathrm{~m}$ could be concluded as follows:

1. Poor practical harvesting tools, where the traditional stalk hook still used up to now and picked the fruits without a part of its twig results in undesired spots on skin caused by sap burn which decrease the fruit quality.

2. Increasing the injured/bruised due to falling impact on the ground causing spoilage to other healthy fruits during packaging and storage and resulting in decay, poor quality and attract low price

3. The traditional methods delayed harvesting, labor-intensive employment and consume a lot of energy. In addition to the risk of climbing tall trees or using ladders on the pickers while picking,

From the stand point of view these problems were encouraged the researches to find out the appropriate harvesting machinery and tools that solve these problems. Therefore, the aim of the present study is to design and fabricate four simple, low cost and portable mechanical harvesting aid of mango fruits for fresh marketing and exporting that assure having fair fruit quality with minimal twig height, and maximizing manual labor productivity in order to minimize the cost of manual picking.

\section{1-Materials}

\section{MATERIAL AND METHODS}

In this study, four designed prototypes of mechanical harvesting aid namely mechanical disk cutter, electrical disk cutter, electrical scissors and cutting edge hook were designed and locally fabricated at some private workshops in El-Mansoura and Damnhour cities, Egypt. The construction and the main components of the fabricated harvesters could be explained as follows:

1- Mechanical disk cutter

The mechanical disk cutter (Fig., 1) is constructed from the following components: 


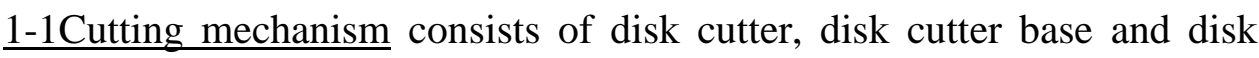
cover. The disk cutter $(\phi=16 \mathrm{~mm})$ fabricated from rigid steel and equipped with corrugated sharpened cutting edge. The cutter was fixed on the disk cutter base with a ball bearing which was fixed on the upper end of the telescopic carrier and rotating cutter shaft. The disk cutter was provided with metal cover to protect the disk cutter during rotating it. A part $(5 \mathrm{~cm})$ on disk cutter circumference remains only without cover for cutting fruit twigs.

1-2 Telescopic carrier consists of two hallow aluminum pipes $3 \mathrm{~m}$ length for each. The upper one $(\phi=16 \mathrm{~mm})$ was inserted into the lower one $(\phi=20 \mathrm{~mm})$ to adjust the height of disk cutter. By this telescopic carrier can be easily pick mango fruits from a height of about 7 meter. However, for picking fruits at higher level, another pipe $(\phi=24 \mathrm{~mm})$ can be extended and fixed in lower position pipe with a screwed wing nut.

$\underline{1-3}$ Fruits collection basket consists of basket rim $(\phi=25 \mathrm{~cm})$ which fabricated from metal ring and equipped with nylon bags on its circumference ( $30 \mathrm{~cm}$ deep). The catching bag could be fabricated locally from strong cord or sewn from canvas. The fruits basket was fixed on the telescopic carrier just under the disk cutter with about $20 \mathrm{~cm}$ to receive and collect the picked fruits during picking process. The basket of mango fruits was relatively small which holds no more 5-6 fruits to avoid increasing fruit weight which affecting on the balance of picker especially on high levels tree, and falling the fruits on the ground.

1-4 Power source and transmission system consist of :-

- A gasoline engine of $1.47 \mathrm{~kW}$ was used to supply the rotational motion for the disk cutter with a range of 600-2000 rpm as shown in Fig. (1).

- A cable (passed through a flexible case to protect it) was used to transmit the power from engine to clutch. The clutch was fixed at the proper place for labor hands on the lower link of telescopic carrier to connect and disconnect the power cable to rotating cutter shaft.

- The power cable (10m length) fabricated from flexible wire steel with square sectional of $2 \times 2 \mathrm{~cm}$ for its two ends. 
- The cutter shaft was used to transmit the power from clutch to the disk cutter through the telescopic carrier.

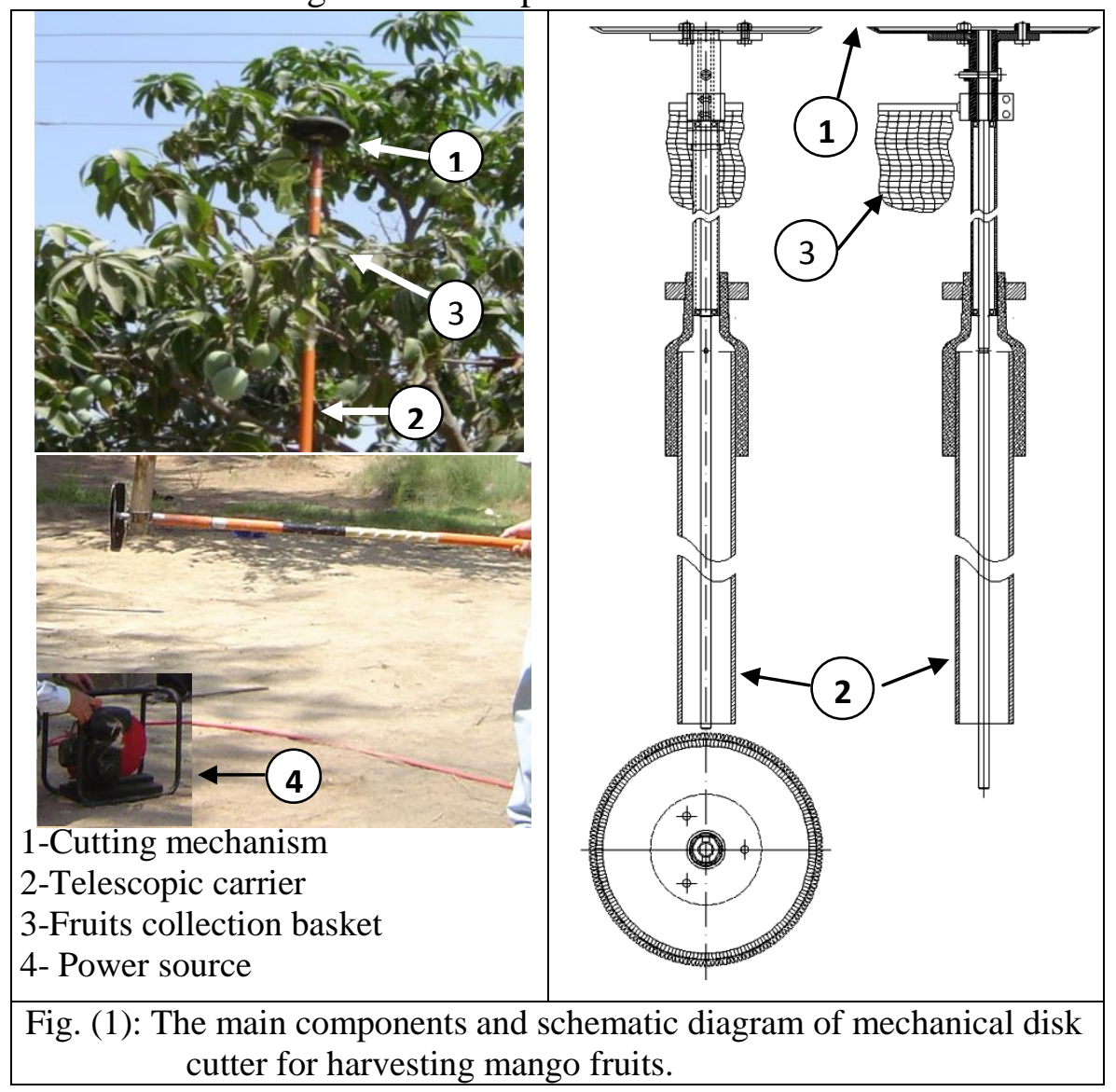

\section{2- Electrical disk cutter}

Except the power source type the electrical disk cutter is constructed from the same main components of mechanical disk cutter, which are cutting mechanism, telescopic carrier and fruits collection basket as shown in Fig. (2). However, the main differences between the mechanical and electrical disk cutter are the power source, its accessories and its position to the disk cutter. Whereas, an electrical DC motor (200 $\mathrm{rpm})$ was used as a power source for rotating disk cutter. A battery $(12 \mathrm{~V}$, 70Ah), wiring cables and on/off switch were used for connecting the motor with on/off switch and battery to complete the electrical operation circuit. 


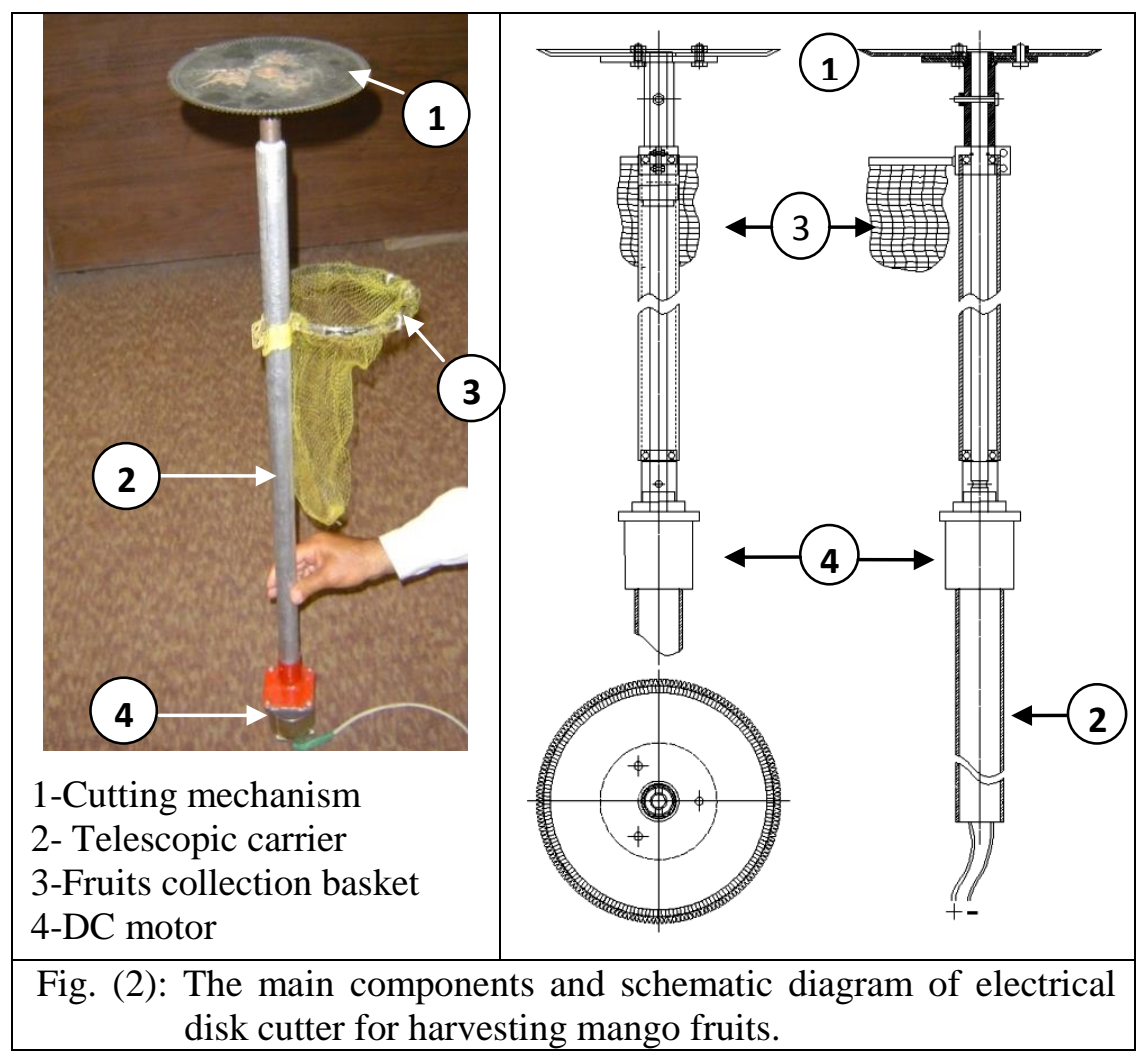

\section{3- Electrical scissors}

The main components of electrical scissors harvesting tool includes cutting mechanism, housing mechanism and fruits collection basket (Fig. 3) could be described as follows:

3-1 Cutting mechanism consists of :

a) Scissors wings, one of them is fixed and other is movable

b) Scissors cam, for converting the rotational speed into reciprocating speed for mobile scissor to apply the cutting action on fruit twig.

c) Electric DC motor as the power source for the reciprocating speed of the scissors and its accessories of battery $(12 \mathrm{~V}, 70 \mathrm{Ah})$,wiring cable and on/off switch for operation circuit of the electrical motor.

d) Scissors base, for fixing electrical motor with the cam and scissors.

3-2 Positioning and housing mechanism for changing the scissors height according the fruit height on the tree (7-10m) and adjusting cutting 
angle of selected fruits to be harvested and carrying out the cutting mechanism at the upper end of it.

3-3 Fruits collection basket exhibits the same main parts and dimensions of that basket included in mechanical disk cutter.

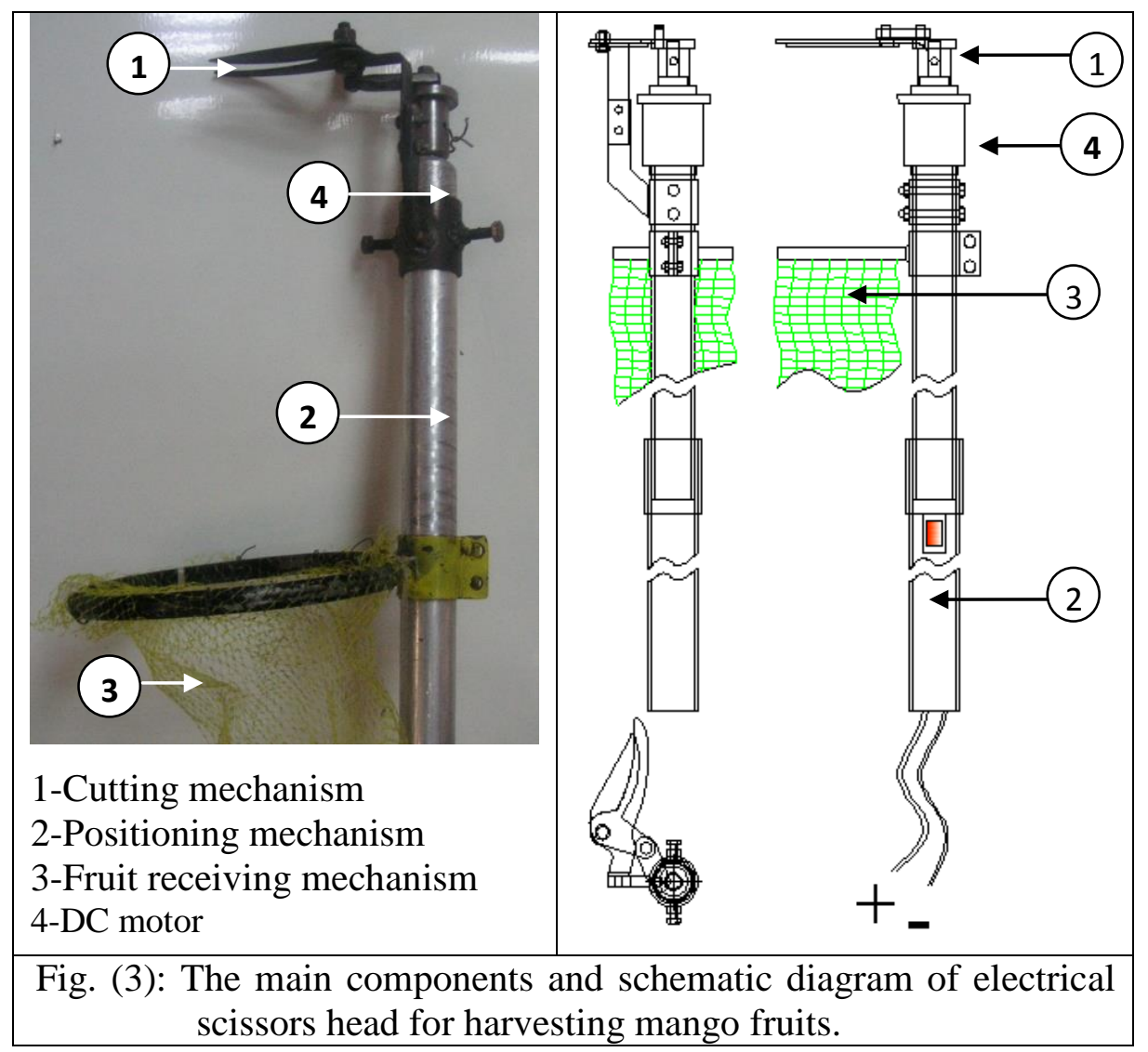

\section{4- Cutting edge hook}

The prototype of the designed cutting edge hook is constructed from the following main parts as indicated in Fig. (4).

4-1 Cutting tool which is fixed at the upper end of telescopic carrier. It consists of two wings of metal like $\mathrm{V}$ letter and the sharp cutting edge was fixed on the upper surface of $\mathrm{V}$ two metal wings end by two bolts to be easy for change and sharp. The cutting edge should be kept sharpened and can be fabricated locally from steed metal or recycled scrap metal. 
4-2 Telescopic carrier used to adjust the proper height of cutter hook at the fruit place on the tree branches. It consists of two hallow aluminum pipes $3 \mathrm{~m}$ length for each. The upper one $(\phi=16 \mathrm{~mm})$ is inserted into the lower one $(\phi=20 \mathrm{~mm})$. Another pipe $(\phi=24 \mathrm{~mm})$ can be extended and fixed in lower position pipe with a screwed wing nut used for picking fruits at higher level.

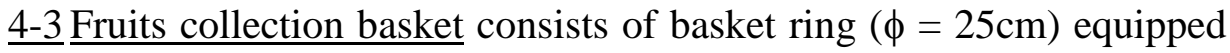
with nylon bags (30 $\mathrm{cm}$ deep) on its circumference. The fruits basket was fixed on the telescopic carrier just under the cutting tool of hook with about $20 \mathrm{~cm}$ to receive and collect the picked fruits during picking process..

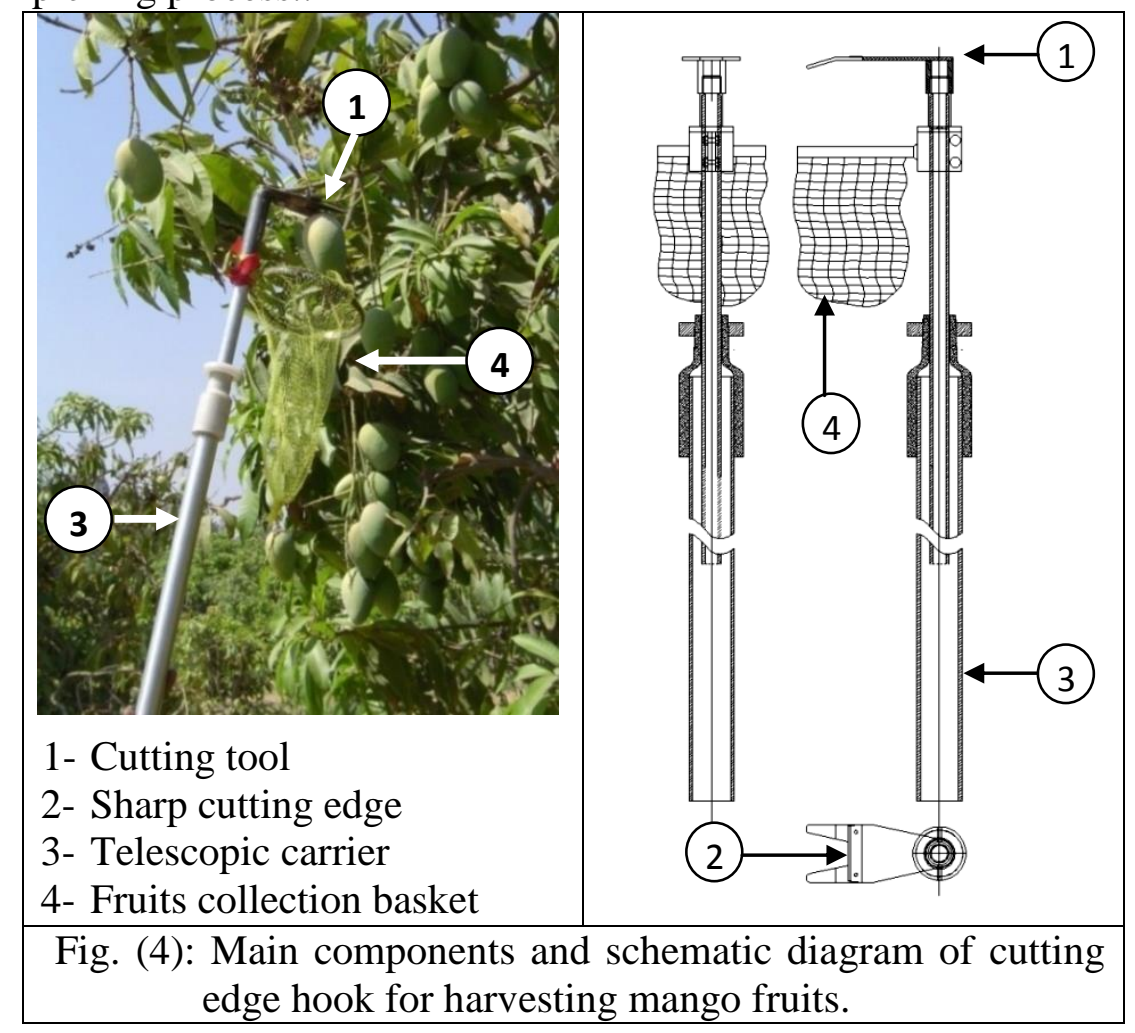

\section{5- Traditional stalk hook}

The traditional stalk picking hook of mango fruits is consists of long stalk made from some tree branches or light weight material (about $5-6 \mathrm{~m}$ length, $6-8 \mathrm{~cm}$ diameter). It provided with steel loop $(\phi=1.5 \mathrm{~cm})$ which fixed on the upper end of the long stalk hook as shown in Fig. (5). The 
labor catch this traditional hook by one hand and pulled the matured mango fruits from its twigs on tree branches, while its other hand tray to receive the pulled fruit and put it in the fruits basket that is often carried on his shoulder.

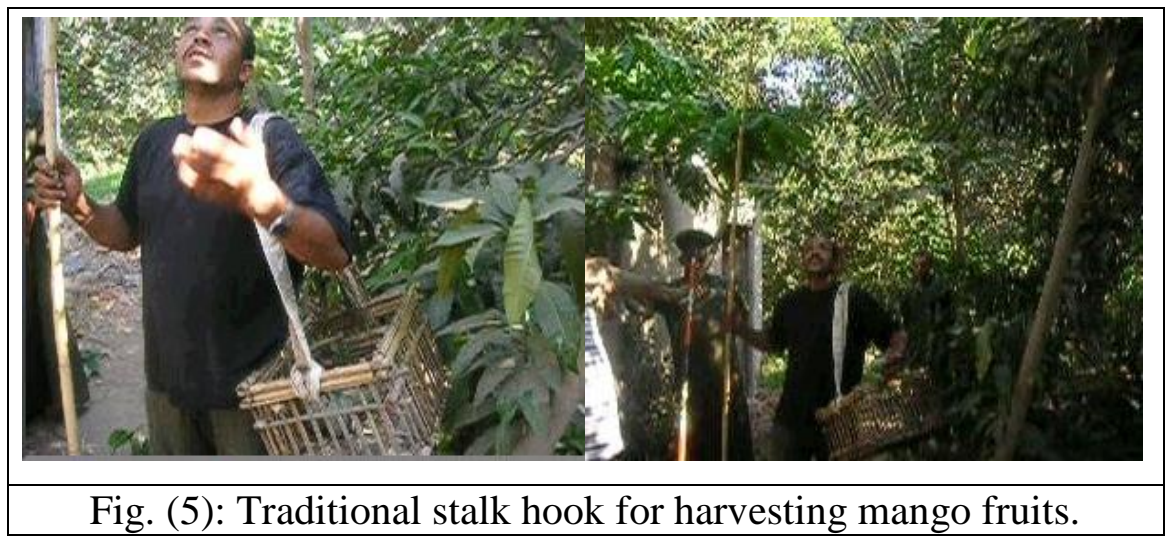

\section{2-Working method of mechanical harvesting aids:}

The operation method of the fabricated harvesters under study is so simple whereas the operator (labor) select the mature mango fruit on the tree branches during standing on ground (i.e., without climbing up on the tree) and detected it by positioning the harvesting aids to the mango fruit twigs. Then the operator activated the detachment action for each aid. Consequently, the fruit is separated and falls into fruits basket. After the basket is full with fruits, the operator moves it downward and empties it in a fruit box.

\section{3- Evaluation experiments and measurements}

All designed prototypes of mechanical harvesting aids under study were evaluated and tested comparing with traditional stalk hook for harvesting Zebda and Hindi mango fruit varieties (mangifera indicia L.) using three different labors for picking process for each harvesting tool under study. The field experiment were carried out during two mango harvesting seasons namely 2008 and 2009 at the mango farms in Kerdasa, El-Giza Gov.; El-Salhia, EL-Sharkia, Gov. and El-Kssassin, Ismailia Gov. During carrying out the field experiments, the following measurements were taken into consideration: 


\section{3-1 Mango tree characteristics}

Mango tree crown characteristics that effect on the performance of designed harvesting tools such as, tree height, tree crown diameter, height of the $1^{\text {st }}$ branch and tree spacing were investigated and measured.

\section{3-2 Mango fruit properties}

The main physical and mechanical properties of Zebda and Hindi mango fruits varieties under investigation, that effect on the performance of the designed harvesting tools were determined before picking mango fruits. The measured physical properties included fruit dimension (length, D1 and diameter, D2), mass, volume, specific weight and fruit twig length/diameter. While, the measured mechanical properties included fruit detachment force, fruit penetration resistance and fruit firmness. Three random samples of fruits (each sample of 20 fruits) were taken from the two mango fruit varieties under study for measuring fruit properties and its twig.

\section{3-3 Total harvesting time and productivity}

The total harvesting time and labor productivity were used as an indicator to evaluate the performance of designed harvesting prototypes in comparison with traditional stalk hook. The total harvesting time was recorded during 4 continues working hours to estimate the average labor productivity (ton/h) using different harvesting tools under study. The total harvesting time (h/ton) includes selecting, detecting and detaching cutting fruit to be harvested, collecting or gathering detached fruits in the basket and emptying it. In addition to, the time required for moving harvesting tools between trees inside the field.

\section{3-4 Quality of harvested mango fruits:}

The quality of harvested fruits was evaluated by calculating the percentage of the damaged fruits due to falling it out of collection basket and the visible damage percentage in the picked fruits due to cutting it by picking tools or falling on the ground. The percentage of good fruit quality was calculated from the collected fruits in the catching basket for each picking method using two mango fruit varieties under study. Also, 
the validity of harvested fruits by mechanical and manual picking methods was estimated by storing it for a period of two weeks under the room temperature.

\section{RESULTS AND DISCUSSION}

\section{1- Mango tree crown characteristics}

The obtained results indicated that there are no observed differences between the tree crowns characteristics for Zebda and Hindi mango varieties under study. The average values of crown diameter were ranged from 6 to $10 \mathrm{~m}$, whereas, the mango trees height reach to $8-12 \mathrm{~m}$ for both mango varieties. However, the first main branch starts at 1.5 to $6 \mathrm{~m}$ from the ground surface with 2-4 main branches for each tree. The average value of mango trees spacing was $6 \times 6 \mathrm{~m}$ for both mango fruit varieties.

\section{2- Mango fruits properties}

The measured physical and mechanical properties of both Zebda and Hindi mango fruit varieties are summarized in Table (1). These results indicated that the physical properties of Zebda mango fruits recorded higher values than that obtained with Hindi mango fruits. Also, it could be observed that the average values of all measured mechanical properties of Hindi mango fruits variety were lower than that obtained with Zebda mango fruits variety. That is may be due to increase the fiber content percentage in Zebda mango fruit variety.

Table (1): Physical and mechanical properties of mango fruits (average values $\pm S D$ ).

\begin{tabular}{|c|l|c|c|}
\hline \multicolumn{2}{|l|}{ Properties } & Hindi variety & Zebda variety \\
\hline \multirow{4}{*}{ Physical } & D1, $\mathrm{mm}$ & $\mathbf{1 1 7 . 5 7} \pm 19.68$ & $\mathbf{1 5 1 . 1 8} \pm 20.91$ \\
\cline { 2 - 4 } & $\mathrm{D} 2, \mathrm{~mm}$ & $\mathbf{6 3 . 9 8} \pm 16.87$ & $\mathbf{8 9 . 3 2} \pm 18.41$ \\
\cline { 2 - 4 } & Volume, $\mathrm{cm}^{3}$ & $\mathbf{1 3 1 . 6 7} \pm 31.93$ & $\mathbf{3 1 8 . 7 1} \pm 39.11$ \\
\cline { 2 - 4 } & Mass, $\mathrm{g}$ & $\mathbf{2 4 3 . 5 1} \pm 36.43$ & $\mathbf{6 1 4 . 1 2} \pm 37.81$ \\
\cline { 2 - 4 } & Specific weight, $\mathrm{g} / \mathrm{cm}^{3}$ & $\mathbf{1 . 8 4 9}$ & $\mathbf{1 . 9 2 7}$ \\
\hline \multirow{2}{*}{ Mechanical } & Detachment force, $\mathrm{N}$ & $\mathbf{3 5 . 1 9} \pm 11.49$ & $\mathbf{5 1 . 3 1} \pm 21.13$ \\
\cline { 2 - 4 } & Firmness, $\mathrm{N}$ & $\mathbf{8 9 . 1 5} \pm 23.29$ & $\mathbf{1 6 6 . 8 5} \pm 31.51$ \\
\hline
\end{tabular}




\section{3- Total harvesting time and productivity}

The average values of total time for harvesting both Zebda and Hindi mango fruit varieties using the designed aid harvesting tool under study was estimated comparing with traditional stalk hook. The obtained results indicated that the highest average values of total time were recorded for traditional stalk hook $(6.74$ and $7.94 \mathrm{~h} /$ ton $)$ while the lowest values were recorded with mechanical disk cutter $(1.34$ and $1.50 \mathrm{~h} /$ ton $)$ for harvesting Zebda and Hindi mango fruit varieties, respectively. However, the electrical scissors recorded 2.14 and $2.33 \mathrm{~h} /$ ton followed by electrical disk cutter $(2.32$ and $2.41 \mathrm{~h} /$ ton$)$ and cutting edge hook (4.33 and $5.27 \mathrm{~h} /$ ton) for harvesting Zebda and Hindi mango fruit varieties, respectively.

The total harvesting time obtained with electrical disk cutter more than mechanical disk cutter may be due to the lowering rotational speed of electrical motor which increase the fruit cutting time and lost time. Decreasing the total harvesting time for mechanical/electrical disk cutter and electrical scissors comparing to other tools may be due to the direct fruit collection in catching basket by these tools. Also it could be noted that the values of the total time consumed for harvesting 1 batch of Zebda mango fruit variety (5 fruits) were 14.83, 23.62, 25.66, 47.88 and 74.45 second, while, it were 7.86, 12.27, 12.67, 27.70 and 41.74 second for Hindi mango fruit variety (6 fruits) using mechanical disk cutter, electrical scissors, electrical disk cutter, cutting edge hook and traditional stalk hook, respectively.

The labor productivity (ton/h) for harvesting both Zebda and Hindi mango varieties using the designed aid harvesting tool under study was estimated comparing with traditional stalk hook. The obtained results for each labor and the average values of labor productivity (ton/h) were illustrated in Fig (6). These results indicated that the labor productivity values were varied from labor to other according to his experience and skill. Also, these results cleared that using the mechanical disk cutter as a mechanical aid harvesting tool gave the highest labor productivity 0.745 and 0.669 ton/h flowed by electrical scissors 0.468 and 0.429 ton/h for harvesting Hindi and Zebda mango fruits, respectively. However, the 
labor productivity by using electrical disk cutter were 0.431 and 0.415 ton/h flowed by 0.231 and 0.190 ton/h by using the cutting edge hook comparing with 0.148 and 0.126 ton/h using the traditional stalk hook for harvesting Hindi and Zebda mango fruits, respectively as shown in Fig. (6).

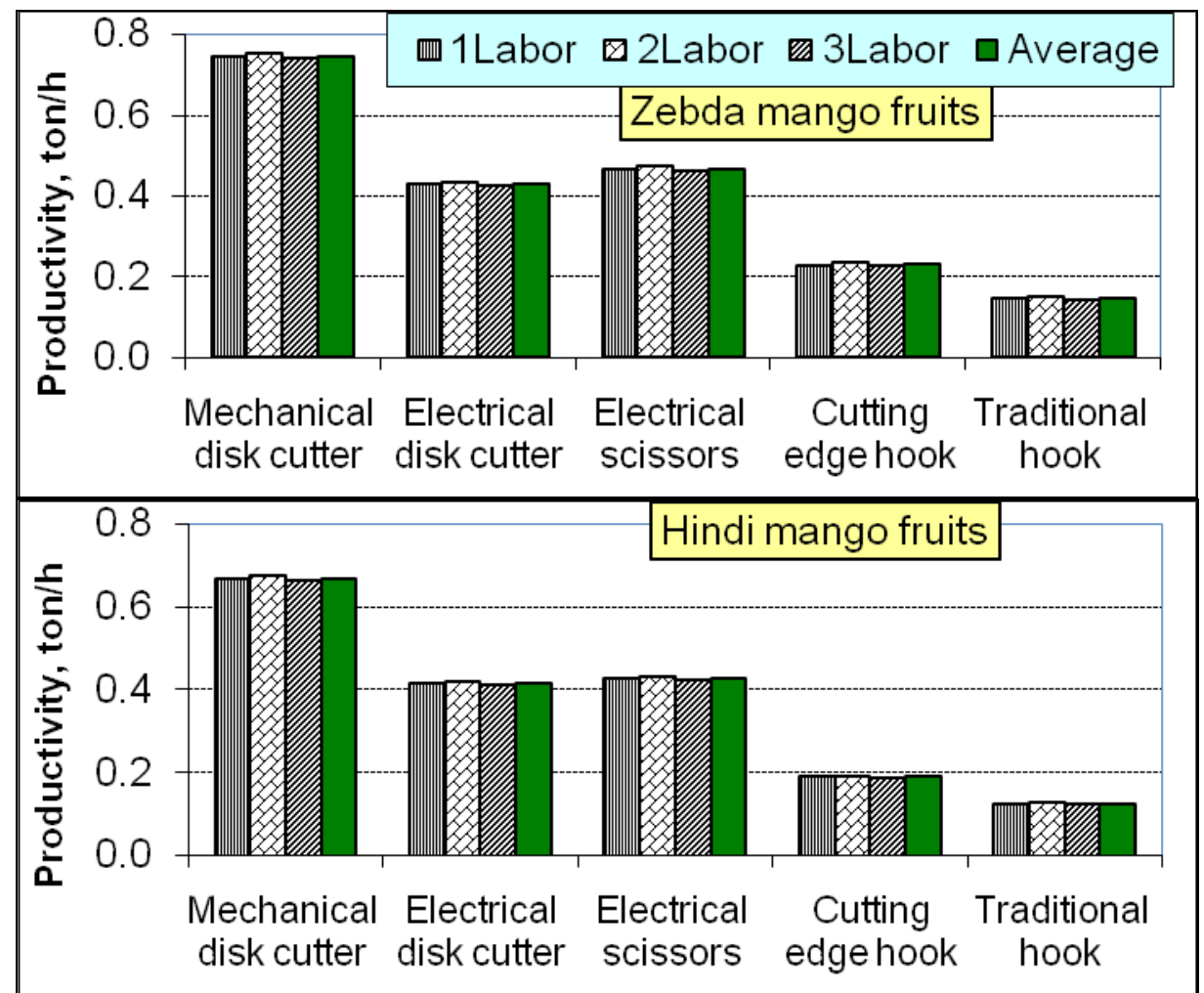

Fig. (6): The labor productivity using different aid harvesting tools comparing with traditional hook for harvesting mango fruits.

The increment percentage in the labor productivity using different mechanical aid harvesting tools for harvesting mango fruits comparing with traditional stalk hook was calculated and illustrated in Fig.(7). The obtained results indicated that the labor productivity increased by about 430.8, 240.1, 229.4 and 50.7\% for harvesting Zebda mango fruits by using the mechanical disk cutter, electrical scissors, electrical disk cutter and cutting edge hook instead of using traditional stalk hook, respectively. However, it were 401.9, 215.2, 190.1 and 55.5\% during harvesting Hindi mango fruits by using the mechanical disk cutter, 
electrical scissors, electrical disk cutter and cutting edge hook instead of using traditional stalk hook, respectively.

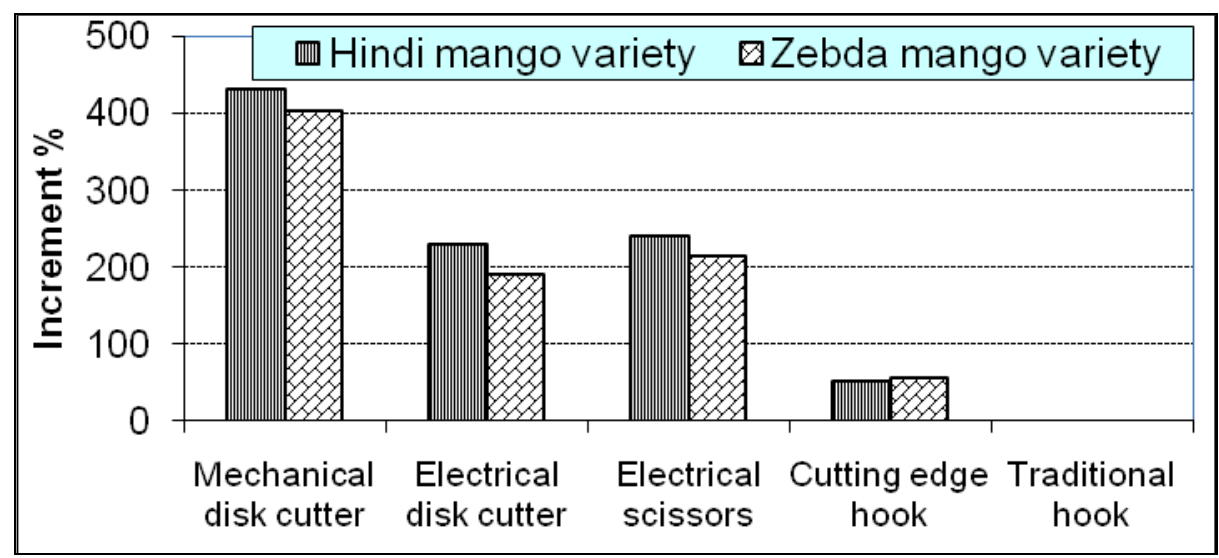

Fig. (7): The increment percentages in labor productivity due to using different aid harvesting tools comparing with traditional hook for picking mango fruits.

Comparing the obtained results of labor productivity for harvesting Hindi and Zebda mango fruit varieties buy using different mechanical aid harvesting tools under study, it could be concluded that the average values of labor productivity for harvesting Zebda mango fruits were higher than that obtained during harvesting Hindi mango fruits for all given aid harvesting tools. These results may be due to big size and high mass of Zebda fruits which decrease the number of harvesting batches and the lost time in emptying fruit basket, consequently increasing the labor productivity. The average values of increment percentage in labor productivity for harvesting Zebda mango variety comparing with Hindi mango variety were $11.4,3.8,9.2,21.6$ and $17.8 \%$ by using mechanical disk cutter, electrical disk cutter, electrical scissors, cutting edge hook and traditional stalk hook, respectively.

\section{4- Quality of picked mango fruits:}

The falling percentage of mango fruits on the ground (out of catching basket), the percentage of injured fruits by aid harvesting tools, the validity storage period and the length of remain part of fruit twig after picked it were measured and calculated as indicators for clearing the 
quality of harvesting mango fruits using mechanical disk cuter, electrical disk cutter and cutting edge hook instead of using traditional stalk hook. The obtained results were summarized in Table (2) cleared that the highest values of injured fruits percentage ( 25-30 and 22-25\%) were recorded by using the traditional stalk hook following by the cutting edge hook (10-12 and 9-10\%) for harvesting Zebda and Hindi mango fruits varieties, respectively. These results may be due increasing injured / bruised fruit percentage due to impact the falling fruits on the ground out of the fruit basket from higher levels of fruit distribution layers on the mango resulting in decay, poor quality and attract low price.

Table (2): Effect of using mechanical aid harvesting tools on the mango fruits quality.

\begin{tabular}{||l||l||c|c|c|c||}
\hline \hline $\begin{array}{c}\text { Mango } \\
\text { Variety }\end{array}$ & Harvesting tool & $\begin{array}{c}\text { Falling } \\
\text { fruits on } \\
\text { ground, } \%\end{array}$ & $\begin{array}{c}\text { Injured } \\
\text { fruits }\end{array}$ & $\begin{array}{c}\text { Storage } \\
\text { period }\end{array}$ & $\begin{array}{c}\text { Remain } \\
\text { twig } \\
\text { length }\end{array}$ \\
\hline \hline \multirow{3}{*}{ Zebda } & Mechanical disk cutter & 4 & $5-6$ & $6-7$ days & $>5 \mathrm{~cm}$ \\
\cline { 2 - 6 } & Electrical disk cutter & 3 & $4-5$ & $6-7$ days & $>5 \mathrm{~cm}$ \\
\cline { 2 - 7 } & Electrical scissors & 4 & $3-4$ & $6-7$ days & $>5 \mathrm{~cm}$ \\
\cline { 2 - 7 } & Cutter hook & 10 & $10-12$ & $4-5$ days & $2-3 \mathrm{~cm}$ \\
\cline { 2 - 7 } & Traditional hook & 25 & $25-30$ & $4-5$ days & $0-1 \mathrm{~cm}$ \\
\hline \hline \multirow{3}{*}{ Hindi } & Mechanical disk cutter & 3 & $4-5$ & $8-9$ days & $>5 \mathrm{~cm}$ \\
\cline { 2 - 7 } & Electrical disk cutter & 3 & $3-4$ & $8-9$ days & $4-5 \mathrm{~cm}$ \\
\cline { 2 - 7 } & Electrical scissors & 4 & $3-4$ & $8-9$ days & $4-5 \mathrm{~cm}$ \\
\cline { 2 - 7 } & Cutter hook & 8 & $9-10$ & $5-6$ days & $2-3 \mathrm{~cm}$ \\
\cline { 2 - 7 } & Traditional hook & 23 & $22-25$ & $5-6$ days & $0-1.5 \mathrm{~cm}$ \\
\hline \hline
\end{tabular}

However, the lowest values of injured fruit percentage (3-4 and 3-4\%) were obtained by using electrical scissors followed by electrical disk cutter (3-4 and 4-5\%), then mechanical disk cutter (5-6 and 4-5\%) for harvesting Zebda and Hindi mango fruits varieties, respectively. These results may be due to decreasing the falling fruit percentage on the ground. The same trends were obtained for the validity storage period of mango fruits, where, the highest values of validity period were 6-7 days and 8-9 days for harvesting Zebda and Hindi mango fruits varieties, 
respectively by using any of mechanical disk cutter, electrical scissors and electrical disk cutter.

Meanwhile, using the traditional stalk hook gave the lowest validity storage period of 4-5 days and 5-6 days for harvesting Zebda and Hindi mango fruits varieties, respectively. The average values of fruit twig length remain in the picked fruits were $0-1.5 \mathrm{~cm}$ by using traditional stalk hook. These results increased to $2-3 \mathrm{~cm}$ by using any of mechanical disk cutter, electrical scissors and electrical disk cutter for harvesting Zebda and Hindi mango fruits varieties. From these results it could be cleared that, increasing the length value of remain fruit twig secure and avoid the undesired spots on skin caused by sap burn which results in poor quality and attract low price.

\section{CONCLUSIONS AND RECOMMENDATIONS}

The obtained results allow us to drawn the following conclusions:

- The labor productivity increased by about 430.8, 240.1, 229.4 and $50.7 \%$ for harvesting Zebda mango fruits and about 401.9, 215.2, 190.1 and $55.5 \%$ during harvesting Hindi mango fruits by using by using the mechanical disk cutter, electrical scissors, electrical disk cutter and cutting edge hook instead of using traditional stalk hook, respectively.

- The lowest values of injured fruit percentage (3-4 and 3-4\%) were obtained by using electrical scissors followed by electrical disk cutter (3-4 and 4-5\%), then mechanical disk cutter (5-6 and 4-5\%) for harvesting Zebda and Hindi mango fruits varieties, respectively. However, the highest values of validity period were 6-7 days and 8-9 days for harvesting Zebda and Hindi mango fruits varieties, respectively by using any of mechanical disk cutter, electrical scissors and electrical disk cutter.

- The authors recommended to locally fabricate and use any of the mechanical disk cutter, electrical scissors and electrical disk cutter for harvesting mango fruits to increase the rate of local fresh market and exporting, in addition to reducing picking cost and increasing the national income. 


\section{REFERENCES}

Abu-Goukh, A. A. and H. I. Mohamed (2004) Effect of harvesting method on quality and shelf-life of mango fruits. Department of Horticulture, Faculty of Agriculture, University of Khartoum, PO Box 321, Khartoum North, Sudan

AOAD (2009). Arab Agricultural Statistics Yearbook - VOL. No. (29), Khartoum, (http://www.aoad.org).

Jarimopas, B. and S. Pataweerat (1993). Evaluation of mango harvesting methods at Nakhon Pathom. Kasetsart J. (Nat. Sci. Suppl.) Vol., : 27, 94-100, Thailand.

Kitinoja, L. and A. A. Kader (2002). Small-Scale Postharvest Handling Practices: A Manual for Horticultural Crops (4th Edition) Postharvest Horticulture Series No. 8A. University of California, Davis, Postharvest Technology Research and Information Center.

Mukherjee, K. (1996). Introduction: Botany and importance. In: Litz R.E. the mango. Botany, production and uses, CAB international. Wallingford oxonoxio 8DE UK.7-17.

Pataweerat, S. (1989). Farm machinery in fruit harvesting. Paper presented for training course in Technology for high quality fruit production. Chantaburi Horticultural Research Center. Horticultural Research Institute, Department of Agriculture, Chantaburi pp. 7495.

Pataweerat,. T. Kakanakup, P. Montviset and A. Terdwongvorakul (1990). Design and development of fruit harvesting tools. Research report. Division of Agricultural Engineering. Department of Agriculture, Bangkok. 44 p.

Peterson, D.L. and S.S. Miller (1988). Advances in mechanical harvesting of fresh market quality apples. J. Agric. Engng. Res. 42:43-50

Ryall, A.L. and W.T. Pentzer (1982). Handling, Transportation and Storage of fruit and Vegetable.2nded.,AvI Publ. Co. Inc., Westport, Connecticut. $610 \mathrm{p}$. 
Weor, D.U (2007). Effects of Various Harvesting Methods and Storage Environments on the Storability of Peter Mango Fruits in Gboko, Benue State, Nigeria. J. of Sustainable Development in Agriculture \& Environment Vol. 3:81-88 Sept. 2007 ISSN 07948867@Paraclete Publishers.

\section{Acknowledgement}

This study is continues work out of the project (Picking Machines for some fruit crops, February 2004 - August 2006) which was financed by Academy of Scientific Research and Technology (ASRT). The authors would like to express deepest appreciation to late prof. Dr. Atef Soliman Hamam the PI of this project.

\section{الملخص العربي}

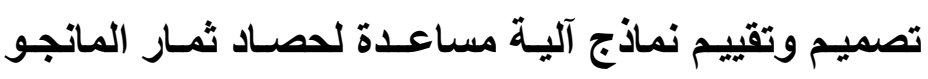

د.محمود العراقى (") ، أ.د يوسف شاروبيم (؛)، د.صفوت الخواجة (r)

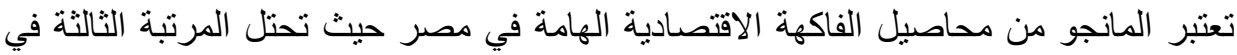

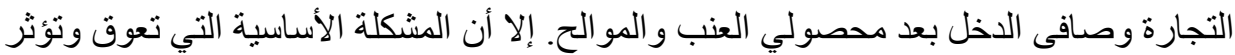

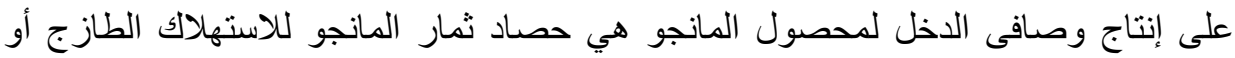

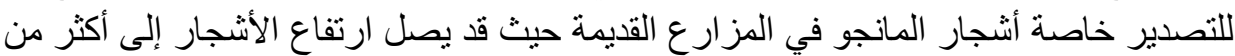

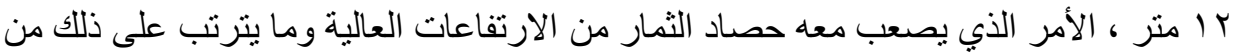

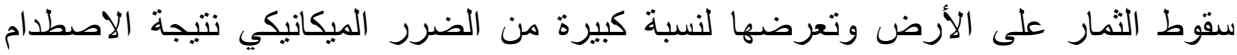

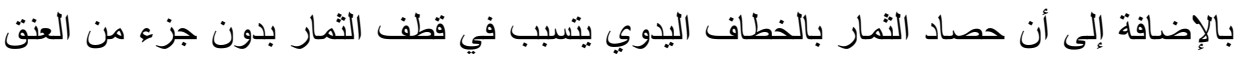

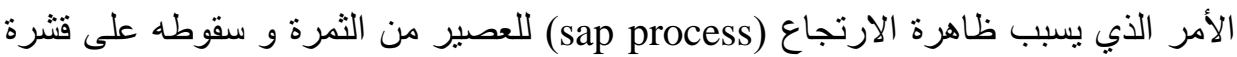

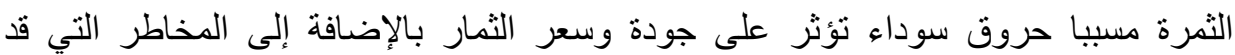

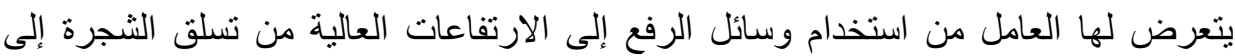

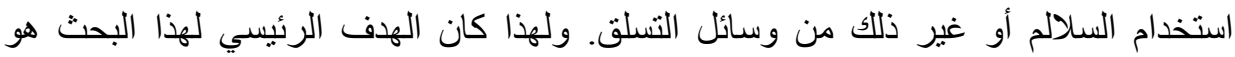

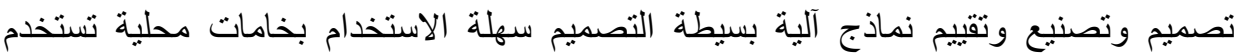

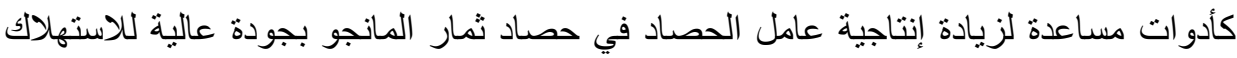
و التداول الطازج في الأسواق المحلية و التصديرية

$$
\text { r باحث أول معهز بحوث الهندة الزراعية مركز البحوث الزراعية . }
$$

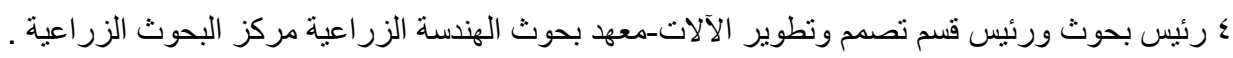


تمت عمليات التصنيع للنماذج تحت الدراسة (السكين القرص الميكانيكي - السكين القرصي الكهربي- المقص الكهربي - الخطاف ذو الحافة القاطعة) ببعض الورش المحلية في مدينتي

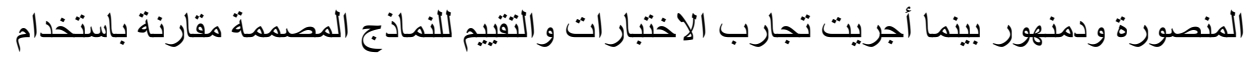
الخطاف اليدوي التقليدي في مزارع إنتاج المانجو الخاصة بـ كرداسة (الجيزة) و الصالحية (الثرقية) ومزرعة مركز البحوث الزراعية بالقصاصين (الإسماعيلية ). وذلك لحصاد ثمار لثار المانجو صنفي زبدة (كبير الحجم) و هندي منوسط الحجم باستخدام ثلاث عمال مختلفة لكل نموذج حصاد لتقييم تأثير ذلك على إنتاجية عامل في الحصاد (طن / ساعة) وجودة الثمار المحصودة. وكانت أهم النتائج المتحصل علئ دليها كما يلي:-

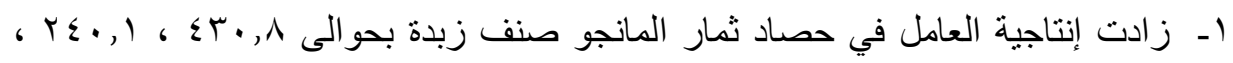

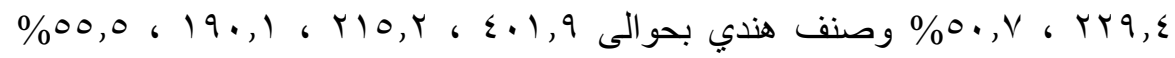
باستخدام نماذج الحصاد السكين القرصي الميكانيكي- السكين القرصي الكهربي و المقص

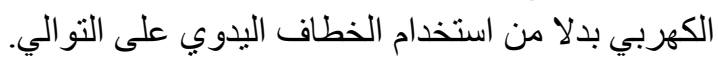

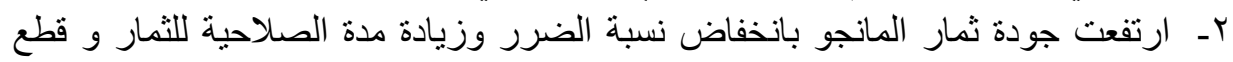

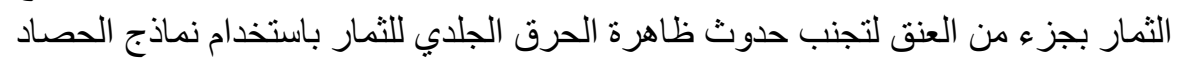

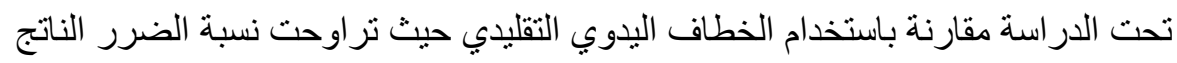

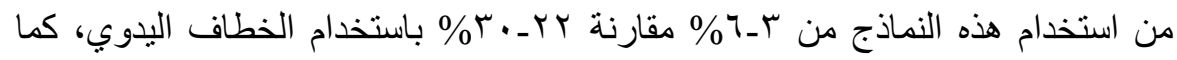

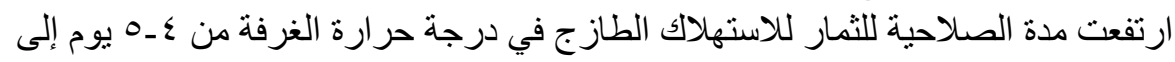

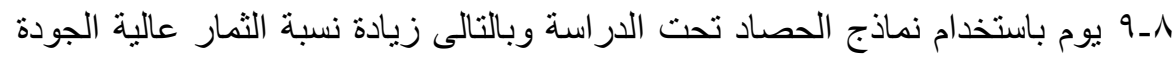

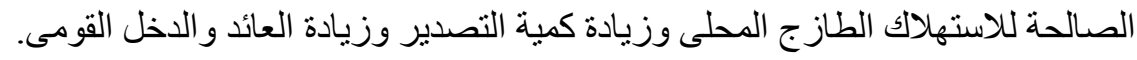

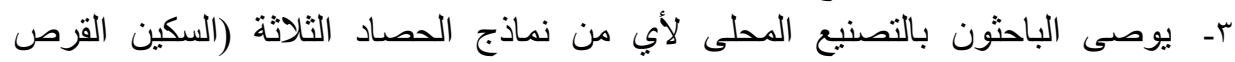
الميكانيكي - السكين القرصي الكهربي- المقص الكهربي) لتوفير نماذج حصاد بسيطة

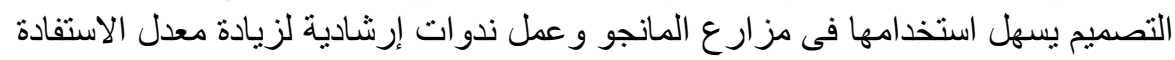
بها، بهدف زيادة إنتاجية عامل الحصاد وتدنية تكاليف الحصاد وتحسين كفاءة عمليات

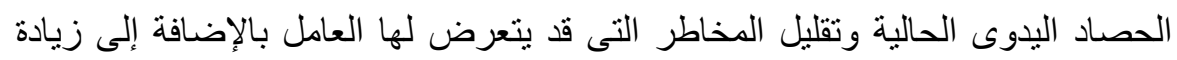

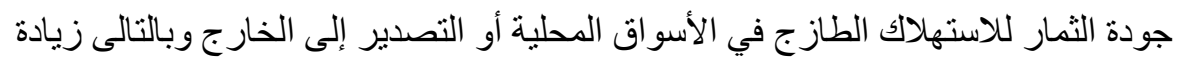

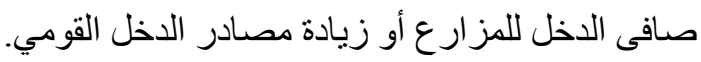

